tekhnolohii navchannia [Information technology training].Tutorial. Zaporizhzhia, 121 p. [in Ukrainian].

6. Morze, N.V. (2006). Osnovy informatsiinokomunikatsiinykh tekhnolohii [Fundamentals of information and communication technologies]. Kyiv, 298 p. [in Ukrainian].

7. Petliushenko, N. (2012). Uprovadzhennia kompiuternykh tekhnolohii u pochatkovii shkoli [Uprovadzhennia kompiuternykh tekhnolohii u pochatkovii shkoli [Introducing computer technology in elementary school]. Primary education and upbringing, No.1, p.12. [in Ukrainian].
8. Ponomarenko, L. (2012). Multymediina pidtrymka navchalnoho protsesu [Multimedia support for the learning process]. Primary education, No.12, p.16. [in Ukrainian].

9. Ryvkind, F.M. (1998). OKH(Osnovy kompiuternoi hramotnosti) [BCL (Basics of Computer Literacy)]. A guide for primary students (developmental learning). Kyiv. [in Ukrainian].

10. Shyman, O.I. (2012). Vykorystannia suchasnykh informatsiinykh tekhnolohii [Use of modern information technologies]. Tutorial. 2nd ed., Suppl. and redone. Zaporizhzhia, 238 p. [in Ukrainian].

Стаття надійшла до редакції 27.08.2019

УДК 377.352/354: 377.44

DOI:

Оксана Самойленко, кандидат педагогічних наук, докторант кафедри педагогіки Житомирського державного університету імені Івана Франка

\title{
КВАЛІФІКАЦІЙНО-КОМПЕТЕНТНІСНИЙ ПІДХІД ДО ПІДГОТОВКИ ФАХІВЦІВ У ЗАКЛАДАХ ВИЩОЇ ОСВІТИ: ЄВРОПЕЙСЬКИЙ ДОСВІД
}

У статті представлено результати розгляду кваліфікаиійно-компетентнісного підходу до підготовки фахівиів у країнах європейської співдружності з метою його перспективного застосування у практику вітчизняних закладів вищої освіти. Виявлено ефективність даного підходу через його практичну спрямованість на формування професійної компетентності фахівиів засобами інтеграції закладу вищої освіти та бізнес-структур. Доведена необхідність врахування запитів ринку праці з метою окреслення змісту навчально-пізнавальної діяльності, який призводить до професійного самовизначення слухача закладу вищої освіти.

Ключові слова: заклад вищої освіти; кваліфікаційно-компетентнісний підхід; ринок прачі.

Jim. 5.

Oksana Samoylenko, Ph.D.(Pedagogy), Doctoral Student of the Pedagogy Department Zhytomyr Ivan Franko State University

\section{THE QUALIFICATION AND COMPETENCE APPROACH TO TRAINING OF EXPERTS IN HIGHER EDUCATION INSTITUTIONS: EUROPEAN EXPERIENCE}

The article presents the results of consideration of the qualification-competent approach to the training of specialists in the countries of the European Commonwealth for the purpose of its future application into the practice of domestic higher education institutions. The basic provisions on the formation of a competent specialist in the countries of the European Union are economic, which stipulates that education should ensure: 1) mastery of future professionals with activities that meet not only professional but also social expectations; 2) the formation of their ability to conscious participation in social processes, 3) their effective socialization.

The effectiveness of this approach is revealed due to its practical orientation on the formation of professional competence of specialists by the means of integration of institutions of higher education and business structures in several stages: 1) the formation of a student's new knowledge; 2) the use of this knowledge in research activities; 3) obtaining a practical result; 4) experimentation with the practical result obtained before its implementation into the technological process of the enterprise or the production process of the business unit; 5) testing of the technological / production process.

The necessity of taking into account labor market demands is proved in order to outline the content of educational and cognitive activity, which leads to the professional self-determination of the student of the institution of higher education. In the context of the above criteria, the competitiveness of an adult in the labor market is the degree of autonomy in the implementation of activities and decision-making and the ratio of reproductive and creative components in the implementation of activities.

Promising for Ukraine is the adaptation of the qualification-competent approach to the conditions of training 


\section{КВАЛІФІКАЦЙНО-КОМПЕТЕНТНІСНИЙПІДХІДДОПІДОТОВКИФАХІВЦІВ У ЗАКЛАДАХ ВИЩОЇ ОСВІТИ: ЄВРОПЕЙСЬКИЙ ДОСВІД}

of specialists in the domestic higher education institutions, which will enable to increase the competitiveness of the adult population in the labor market.

Keywords: an institution of higher education; the qualification-competence approach; a labor market.

П остановка проблеми. Модернізація системи освіти у Європейському Союзі у напрямі формування професійної компетентності фахівця упродовж життя набуває як політичного, так і загальнонаціонального значення. У конститутивних документах $\mathrm{CC} \mathrm{підкреслюється} \mathrm{актуальність}$ завдання забезпечення соціального захисту населення шляхом підвищення рівня його професіоналізму та кваліфікації. Відповідно перший фактор реформування системи освіти у країнах європейської співдружності- економічний, який передбачає, що освіта повинна забезпечувати 1) оволодіння майбутніми спеціалістами діяльністю, яка відповідає не тільки професійним, а й соціальним очікуванням 2 ) формування у них здатності до усвідомленої участі у соціальних процесах, 3) їх ефективну соціалізацію. За такого підходу, за допомогою освіти вирішується ряд важливих суспільних завдань: підготовка дорослого не тільки до професії, а й до нових умов життя, засвоєння досвіду спілкування і норм співжиття, формування особистісних якостей, які відповідають потребам професійної діяльності і суспільства.

Для оптимального вирішення поставлених завдань за основу системи освіти дорослих у країнах європейської спільноти прийнятий кваліфікаційно-компетентнісний підхід, унормований Міжнародним стандартом класифікації освіти (англ. International Standart Classification of Education, ISCED). Вихідною класифікацією ISCED $є$ освітня програма відповідного рівня (від 0 до 6) та галузь освіти (25 галузей, 10 груп). Відповідно ISCED навчальні програми бувають: 1) спрямовані на здобуття вищої освіти, отримання найвищого рівня кваліфікацій, розвитку навичок дослідницької роботи - тип А; 2) спрямовані на продовження навчання поряд 3 оволодінням професійнотехнічними кваліфікаціями - тип В; 3) кінцеві, призначені для підготовки до трудової діяльності, виходу на ринок праці - тип С [5].

Аналіз основних досліджень і публікацій. Аналіз праць вітчизняних дослідників (І. Бевзюк, I. Жукевич, I. Леган, В. Локшин, I. Костікова, Т. Мала, В. Моторіна, Г. Попова, М. Судаков, О. Тімець, М. Яворська та ін.) виявив активний науковий пошук шляхів розв'язання проблеми підготовки компетентнісних фахівців у сучасних ринкових умовах. Важливим у цьому контексті видається вивчення досвіду зарубіжних країн з метою адаптації його до українських соціо-культурних реалій.

Формування мети статті (завдання): здійснити загальний огляд кваліфікаційнокомпетентнісного підходу до підготовки фахівців у країнах європейської співдружності з метою його перспективного застосування у практику вітчизняних закладів вищої освіти.

Виклад основного матеріалу. Кваліфікаційнокомпетентнісний підхід до освіти дорослих у країнах ЄC змінюе цілі освіти загалом: не поінформованість дорослих учнів, а формування у них компетентностей вирішувати життєві та професійні проблеми і завдання на основі отриманих ними знань. Такий підхід виник як синтез американського та британського підходів до визначення компетентнісного бачення якості результатів підготовки фахівців.

У сучасних умовах актуалізуються чинники, які визначають нові вимоги до завершальних характеристик компетентності сучасних фахівців: радикальна зміна змісту і диверсифікація професійної діяльності спеціалістів; висока невизначеність ринку праці, його швидка i непередбачувана мінливість; загострення конкуренції; скасування системи державного замовлення. У зв'язку із зазначеним, здобувачі освіти повинні бути професіоналами не тільки у певній точній області виробництва, але і грамотними, універсальними фахівцями у ряді прикладних напрямів; вони повинні характеризуватися універсальністю і диверсифікованістю своєї професійної компетентності. Лише за цієї умови може бути забезпечена їхня конкурентоспроможність наринку праці.

Грунтовне дослідження конкурентоспроможності молоді на ринку праці проведене вітчизняною дослідницею I. Леган [4], яка на основі синтезу існуючих теоретико-методологічних підходів до окресленого поняття визначає його на нано-, мікрота мезо/макрорівнях:

Конкурентоспроможність молоді на ринку праці на нанорівні - це сукупність особливих здібностей та унікальних переваг молодої людини, які виділяють їі з-поміж конкурентів та визначає iï успіх на ринку праці, сприяє професійному зростанню, покращенню матеріального благополуччя та підвищенню соціального статусу.

Конкурентоспроможність молоді на ринку праці на макрорівні - здатність забезпечувати високий рівень конкурентного статусу на внутрішньо фірмовому ринку праці, утримувати 


\section{КВАЛІФІКАЦЙНО-КОМПЕТЕНТНІСНИЙПІДХІДДОПІГОТОВКИ ФАХІВЦІВ У ЗАКЛАДАХ ВИЩОЇ ОСВІТИ: ЄВРОПЕЙСЬКИЙ ДОСВІД}

високі конкурентні позиції з метою створення конкурентних переваг у відповідності з вимогами роботодавця та можливість досягнення найвищих результатів діяльності суб'єкта господарювання.

Конкурентоспроможність молоді на ринку праці на мезо/макрорівні - здатність відповідати потребам регіону/економіки та суспільства щодо якості робочої сили та формувати сталу конкурентну позицію на (регіональному) ринку праці.

Під конкурентоспроможністю фахівця розуміють також відповідність робочої сили вимогам ринку, можливість вступати у взаємозв'язки конкуренції (конкурувати) на ринку праці; сукупність характеристик, яка визначає порівняльні позиції конкретного працівника або окремих груп на ринку праці і дозволяє йому (їм) претендувати на заняття певних вакансій (найм). У зв'язку із цим, виділяють декілька рівнів здійснення майбутньої професійної діяльності як етапів формування конкурентоспроможності фахівця.

У контексті зазначеного, критеріями конкурентоспроможності дорослого на ринку праці $є$ :

- ступінь самостійності у здійсненні діяльності і прийнятті рішення;

- співвідношення репродуктивного і творчого компонентів при здійсненні діяльності.

Відповідно до вказаних критеріїв, Ю. Давидова виділяє чотири рівні здійснення діяльності [3]:

1 рівень - алгоритмізована діяльність, яка характеризується чіткою детермінацією поведінки фахівця, добре структурованою ситуацією здійснення діяльності та виконанням стандартного набору дій, необхідних на даному робочому місці. Творчий компонент при здійсненні діяльності практично відсутній.

2 рівень - частково самостійна діяльність, характеризується виконанням окремих дій за вказівкою керівництва або згідно з технологічним процесом. На цьому рівні творчий компонент при здійсненні діяльності проявляється, але представлений мінімально.

3 рівень - самостійна діяльність, здійснювана в регламентованих умовах стандартних ситуацій, самостійність суб'єкта діяльності обмежується рамками організації. На цьому рівні спостерігається приблизно рівне співвідношення репродуктивного і творчого компонентів.

4 рівень - самостійна діяльність, здійснювана на творчому рівні, що характеризується прийняттям самостійних рішень у нестандартних ситуаціях, в умовах, що виходять за рамки регламентованої діяльності. На цьому рівні очевидне переважання творчого компонента.
Вважаємо, що спеціаліст-професіонал - це дорослий, який досягнув четвертого рівня виконання діяльності. Тому, кінцевою метою освіти дорослих за кваліфікаційно-компетентнісного підходу є формування особистості, яка активно, компетентно та ефективно бере участь у економічному та соціальному життя суспільства. Крім того, знання специфіки та основ сучасного виробництва не тільки допомагає дорослому оволодіти у подальшому відповідною інженерною спеціальністю, але й робить його професійно мобільним, що $є$ ще однією затребуваною якістю сучасного фахівця.

На думку багатьох вчених заклад вищої освіти повинен стати механізмом, який, використовуючи наукові методи і аналіз стану економіки у різних іiі аспектах, здатний визначити нові ціннісні орієнтири системи освіти, здійснити інтеграцію вимог ринку праці та освітнього процесу, зруйнувавши тим самим розрив між змістом освіти і практичною діяльністю. Особливе значення у цих умовах, як показує досвід Словаччини, набуває інтеграція освіти та бізнесу - процес тривалий та багатовимірний, який, на рівні закладу вищої освіти, проходить у декілька етапів [2]:

1. Формування у студента нового знання.

2. Використання цього знання у науководослідній діяльності.

3. Отримання практичного результату.

4. Експериментування з отриманим практичним результатом до його втілення у технологічний процес підприємства або виробничий процес бізнес-одиниці.

5. Апробація технологічного/виробничого процесу.

Така послідовність інтеграції довела свою життєздатність та перспективність. До прикладу, студенти Технологічного університету у Кошицях (Словацька Республіка) при написанні бакалаврських та дипломних робіт виконують власні технологічні інноваційні проекти для різних бізнес-структур, апробують їх на робочому місці, формують висновки та рекомендації для реалізації у виробничій діяльності. Студенти, які успішно захистили свої проекти, отримують робоче місце на дослідному підприємстві. Таким чином, знімається проблема працевлаштування випускників іпідвищується їх конкурентоспроможність наринку праці.

Студенти Прешовського університету у Прешові (Словацька Республіка) на третьому курсі бакалаврату вчаться за системою дуальної освіти - навчання через практичну діяльність. Студент включається у процес виробництва як 


\section{КВАЛІФІКАЦІЙНО-КОМПЕТЕНТНІСНИЙ ПІДХІДДОППГОТОВКИ ФАХІВЦІВ У ЗАКЛАДАХ ВИЩОЇ ОСВІТИ: ЄВРОПЕЙСЬКИЙ ДОСВІД}

працівник підприємства і виконує обов'язки відповідно до покладених на нього функцій, розпоряджається ресурсами, несе відповідальність, опановує необхідними професійними вміннями та навичками, а в деяких випадках навіть може отримувати заробітну плату за договором. Словацький досвід проказує ефективність співвідношення часу теоретичного і виробничого навчання 40 до $60 \%$ відповідно. Для зручності поділ навчальної діяльності проводиться по днях тижня, наприклад 1 - 2 дні на тиждень студент навчається в аудиторії, в інші дні-на підприємстві.

Такий підхід суголосний з тенденцією до розуміння професійного самовизначення дорослого як “активного самовизначення, що виражається у реальних діях, веде до формування та розвитку тих внутрішніх умов, які створюють можливості для розвитку особистості, формування передумов збільшення рівня професійної придатності, подальшого самовизначення. Професійне самовизначення передбачає формування суб'єкта, що має високу мобільність, широку орієнтацію у світі професійної праці" [1]. В основу підготовки такого спеціаліста покладені знання, уміння та навички у відповідності з професіограмою його діяльності та специфічні педагогічні принципи:

1. Інтеграція - зв'язок професійно-технічного навчального закладу із виробництвом/бізнесом, загальних і професійних знань, теорії і практики.

2. Креативність - формування інтеграційних якостей особистості, які впливають на їі професійне самовизначення і розвиток, здатність до творчої діяльності.

3. Акмеологія - визначення траєкторії професійного зростання, мотивація досягнення результативності, стимулювання розвитку властивостей суб'єктивності.

4. Фундаменталізация-якісна загальнопрофесійна підготовка 3 орієнтацією на саморозвиток особистості дорослого.

5. Випереджаюче навчання - готовність до мобільності у професійному розвитку у контексті сучасних економічних умов.

За кваліфікаційно-компетентнісного підходу модель підготовки фахівців у закладі вищої освіти у країнах Європейського Союзу представляє собою цілісну систему: методів, що сприяють професійному самовизначенню особистості та активної професійної підготовки, яка базується на інформаційно-технологічному забезпеченні всього освітнього процесу.

Виходячи з того, якого фахівця потребує сучасний ринок праці, визначається зміст навчально-пізнавальної діяльності, який призводить до професійного самовизначення слухача закладу вищої освіти. Відповідно до вказаної моделі, процес професійного самовизначення майбутнього фахівця складається із декількох етапів:

1 eman - підготовчий: пов'язаний 3 професійно-психологічним відбором. На даному етапі формується початкова психологічна база професійного самовизначення особистості. Потреба у виборі професії запускає усю систему потреб учня. Особистісні потреби, бажання, інтереси, схильності, морально-етичні якості особистості, які були визначальними при виборі професії призводять до рішення вибрати відповідну професію.

2 етаn - 1 р.н-період адаптаціï: створення соціально-психологічних і педагогічних умов навчання у закладі професійно-технічної освіти. Відбувається осмислення нової ролі, з'являється самооцінка правильності прийнятого рішення, поступово формується ставлення до обраної професії, до особливостей навчального процесу та його вимог.

3 eman - 2-3 р.н - (занурення у cnеціiальність): професійне становлення i підготовка фахівця в умовах закладу професійнотехнічної освіти.

4 етап - (3-4 р.н) становлення фахівия (професійне утвердження) - реалізується стратегія розвитку професійно-психічних якостей слухачів закладу професійно-технічної освіти, доведення їх до бажаного рівня. Відпрацювання професійних навичок у строго визначеному порядку 3 можливістю їх варіювання та індивідуалізації, перестроювання неправильно сформованих професійних умінь і якостей майбутніх фахівців.

5 етап - адаптація на виробництві. У слухачів закладу вищої освіти адаптація виражається у практичному освоєнні професії, передбачає закріплення отриманих знань і навичок з урахуванням конкретного виробництва, розширення професійного кругозору, виконання конкретних реальних виробничих завдань. Критерієм професійної адаптації слухачів закладу вищої освіти $є$ результативність праці у відповідності до заданих умов та вимог виробництва.

Представлена модель професійного самовизначення слухачів закладу вищої освіти Словацькій Республіці є відкритою, соціальною, динамічною та варіативної, дозволяє вносити необхідні перетвори та поточнення відповідно до потреб сучасного ринку праці, не зазнаючи суттєвих змін. 
Висновки дослідження. Проведене дослідження змісту, практичної спрямованості та специфіки кваліфікаційно-компетентнісного підходу до підготовки фахівців у європейських країнах виявило його ефективність. За вказаного підходу слухач закладу вищої освіти легко адаптується до мінливих ринкових умов, набуває якостей конкурентоспроможної особистості, здатної до перетворення соціальної реальності.

До перспектив подальших досліджень відносимо розгляд науково-практичних підходів до підготовки фахівців у вітчизняних закладах вищої освіти з метою окреслення шляхів екстраполяції досвіду європейських країн до української освітньої практики.

\section{ЛITЕРАТУРA}

1. Frk V., Kredátus J. 2007. Komunikácia v personálnej a sociálnej praxi. Kapitoly o sociálnej komunikácii a vedení tímov. Prešov : Akcent Print. $125 \mathrm{~s}$.

2. Mužík J. 2012. Profesní vzdělávání dospělých. 1. vyd. Praha : Wolters Kluwer Česká Republika. 80 s.

3. Давидова В. Д. 2008. Неформальна освіта дорослих у навчальних гуртках Швеції : дис... канд. пед. наук: 13.00.01. Київський національний ун-т ім. Тараса Шевченка. Київ.

4. Леган I. Конкурентоспроможність молоді на ринку праці: шляхи забезпечення та напрями підвищення. дис. ... канд. екон. наук : 08.00.07; НАН України, Ін-т демографії та соц. дослідж. ім. М. В. Птухи. Київ, 2015. 258 с.

5. Мельниченко Р. К. Організація профільного навчання в старшій школі зарубіжжя та його педагогічний супровід (компаративний аналіз) URL: http://eprints.zu.edu.ua/27722/1 (дата звернення: 11.03.2019)

\section{REFERENCES}

1. Frk, V., Kredátus, J. (2007). Komunikácia v personálnej a sociálnej praxi. Kapitoly o sociálnej komunikácii a vedení tímov [Communication in personal and social practice. Chapters on social communication and team leadership]. Prešov : Akcent Print. 125 p. [in Slovakia].

2. Mužík, J. (2012). Profesni vzdělávání dospélých [Professional adult education]. Praha Publ.: Wolters Kluwer Česká Republika. 80p. [in Slovakia].

3. Davydova, V. D. (2008). Neformalna osvita doroslykh u navchalnykh hurtkakh Shvetsii [Adult informal education in Swedish educational circles]. Candidate's thesis. Kyiv. [in Ukrainian].

4. Lehan, I. (2015). Konkurentospromozhnist molodi na rynku pratsi: shliakhy zabezpechennia ta napriamy pidvyshchennia [Competitiveness of youth in the labor market: ways of providing and directions for improvement]. Candidate's thesis. Kyiv. 258 p. [in Ukrainian].

5. Melnychenko, R. K. (2019). Orhanizatsiia profilnoho navchannia $v$ starshii shkoli zarubizhzhia ta yoho pedahohichnyi suprovid (komparatyvnyi analiz) [Organization of profile education in high school abroad and its pedagogical support (comparative analysis)]. Available at: http:// eprints.zu.edu.ua/27722/1 (accessed 11 March 2019) [in Ukrainian].

Стаття надійшла до редакції 29.07.2019

\section{G580}

“ТІочне логічне визначення понять - умова істинного знання".

$$
\begin{array}{r}
\text { Cократ } \\
\text { давньогрецький брілософб }
\end{array}
$$

“Заняття наукою живлять юність $i$ приносять насолоду старості, приқрашають в щасті, служать притулқом і розрадою в нещасті".

Ifичерон

давньоримський політичний діяч, видатний оратор, філософ та літератор

“Освіта повинна бути істинною, повною, ясною $і$ мішною”.

$$
\text { Унсур Аль-Маaлі (Кей Кабус) }
$$

персидський письменник

\section{}

